\title{
On Teaching International Courses on Health Information Systems
}

\section{Lessons Learned during 16 Years of Frank - van Swieten Lectures on Strategic Information Management in Health Information Systems}

\author{
Elske Ammenwerth ${ }^{1}$; Petra Knaup ${ }^{2}$; Alfred Winter ${ }^{3}$; Axel W. Bauer ${ }^{4}$; Oliver J. Bott ${ }^{5,6}$; \\ Matthias Gietzelt ${ }^{2}$; Birger Haarbrandt ${ }^{5}$; Werner 0. Hackl ${ }^{1}$; Nils Hellrung ${ }^{5,7}$; Gudrun \\ Hübner-Bloder1; Franziska Jahn'; Monique W. Jaspers" ${ }^{8}$; Ulrike Kutscha9; Christoph \\ Machan'; Bianca Oppermann"; Jochen Pilz"; Jonas Schwartze ${ }^{5}$; Christoph Seidel ${ }^{10}$; \\ Jan-Eric Slot ${ }^{11,12}$; Stefan Smers ${ }^{13}$; Katharina Spitalewsky ${ }^{2,14}$; Nathalie Steckel ${ }^{5,15}$; \\ Alexander Strübing ${ }^{3}$; Minne van der Haak ${ }^{2,16}$; Reinhold Haux ${ }^{5}$; Willem J. ter Burg ${ }^{8}$ \\ ${ }^{1}$ Institute of Medical Informatics, UMIT - University for Health Sciences, Medical Informatics and Technology, Hall in \\ Tirol, Austria; ${ }^{2}$ Institute of Medical Biometry and Informatics, University of Heidelberg, Heidelberg, Germany; \\ ${ }^{3}$ Institute for Medical Informatics, Statistics and Epidemiology, University of Leipzig, Leipzig, Germany; \\ ${ }^{4}$ History, Philosophy, and Ethics in Medicine, Medical Faculty Mannheim, Heidelberg University, Mannheim, Germany; \\ ${ }^{5}$ University of Braunschweig - Institute of Technology and Hannover Medical School, Peter L. Reichertz Institute for \\ Medical Informatics, Braunschweig, Germany; \\ ${ }^{6}$ Department of Information and Communication, Hannover University of Applied Sciences and Arts, Hannover, \\ Germany; \\ ${ }^{7}$ Symeda GmbH, Braunschweig, Germany; \\ ${ }^{8}$ Department of Medical Informatics, Academic Medical Center, University of Amsterdam, Amsterdam, The \\ Netherlands; \\ ${ }^{9}$ Center of Information Technology and Medical Engineering, University Hospital of Heidelberg, Heidelberg, Germany; \\ ${ }^{10}$ Department for Information Technology and Business Development, Braunschweig Medical Center, Braunschweig, \\ Germany; \\ ${ }^{11}$ IT Academic Center, University of Amsterdam, Amsterdam, The Netherlands; \\ ${ }^{12}$ ICT Department, Bernhoven Hospital, Uden, The Netherlands; \\ ${ }^{13}$ Department for Information Technology, University Hospital of Leipzig, Leipzig, Germany; \\ ${ }^{14}$ Clinical Trial Center (CTCW), University Hospital of Wuerzburg, Wuerzburg, Germany; \\ ${ }^{15}$ Department UK-IT, University Hospital of Bonn, Bonn, Germany; \\ ${ }^{16}$ Siemens AG, Erlangen, Germany
}

\section{Keywords}

Education, strategic information management, health information systems, medical informatics, biomedical informatics, health informatics

\section{Summary}

Background: Health information systems (HIS) are one of the most important areas for biomedical and health informatics. In order to professionally deal with HIS well-educated

Correspondence to:

Prof. Dr. Reinhold Haux

Peter L. Reichertz Institute for Medical Informatics

University of Braunschweig - Institute of Technology

and Hannover Medical School

Muehlenpfordtstr. 23

38106 Braunschweig

Germany

E-Mail: reinhold.haux@plri.de informaticians are needed. Because of these reasons, in 2001 an international course has been established: The Frank - van Swieten Lectures on Strategic Information Management of Health Information Systems.

Objectives: Reporting about the Frank - van Swieten Lectures and about our students' feedback on this course during the last 16 years. Summarizing our lessons learned and making recommendations for such international courses on HIS.

Methods Inf Med 2017; 56(Open): e39-e48 https://doi.org/10.3414/ME16-01-0124 received: October 21, 2016 accepted: February 18, 2017 published: March 8, 2017
Methods: The basic concept of the Frank van Swieten lectures is to teach the theoretical background in local lectures, to organize practical exercises on modelling sub-information systems of the respective local HIS and finally to conduct Joint Three Days as an international meeting were the resulting models are introduced and compared.

Results: During the last 16 years, the Universities of Amsterdam, Braunschweig, Heidelberg/Heilbronn, Leipzig as well as UMIT were involved in running this course. Overall, 517 students from these universities participated. Our students' feedback was clearly positive. The Joint Three Days of the Frank - van Swieten Lectures, where at the end of the course all students can meet, turned out to be an important component of this course. Based on the last 16 years, we recommend common teaching materials, agreement on 
equivalent clinical areas for the exercises, support of group building of international student groups, motivation of using a collaboration platform, ensuring quality management of the course, addressing different levels of knowledge of the students, and ensuring sufficient funding for joint activities. Conclusions: Although associated with considerable additional efforts, we can clearly recommend establishing such international courses on HIS, such as the Frank van Swieten Lectures.

\section{Introduction}

Health information systems (HIS) were, are currently, and, as far as we can see, will also be in future one of the most important areas for biomedical and health informatics. There is a global consensus about their relevance for health care, which, e. g., led in 2005 to the World Health Assembly's eHealth Resolution $[1,2,3]$ and to the implementation of the World Health Organization's Global Observatory for eHealth [4, 5]. Its importance has been emphasized in many publications of our scientific community (e. g. $[6,7,8,9,10])$.

In order to professionally deal with HIS, we need to understand their respective architectures and infrastructures (e. g. the architecture of the information system of a certain hospital, e. g. [11], or of a nation's 'eHealth infrastructure', e. g. [12]), and we need to know how such information systems are adequately managed. In particular, its strategic information management is crucial, both for the quality of care and for the costs of information processing and storage (e. g. [13]).

For being able to do this, well-educated informaticians are needed. The International Medical Informatics Associations (IMIA) has raised this importance, when IMIA's General Assembly adopted recommendations on health and medical education in 1999 [14], and confirmed the relevance for educating informatics students about HIS in its first revision in 2009 [15]. Furthermore, graduates of educational programs in medical informatics frequently work in the area of health information systems $[16,17,18,19,20]$.
Because of these reasons courses on health information systems and their management always played an important role in our universities' educational programs. As our graduates' work became more and more global, we decided in 2000 to establish an international course on this subject, at first under the umbrella of IФE, the International Partnership for Health Informatics Education [21, 22]. Since its start in 2001, this course is focussing on the strategic information management of health information systems as well as on HIS architectures [23, 24]. For this course a textbook was written [25] and recently revised [26]. Since 2005 our course has been called Frank - van Swieten Lectures on Strategic Information Management of Health Information Systems, or, briefly, Frank - van Swieten Lectures.

After having organized and taught the Frank - van Swieten Lectures during 16 years, we decided to review, summarize, and communicate our activities. Our objectives, which lead to this manuscript, are to report and share our knowledge

(O1) about the Frank - van Swieten Lectures (section $2.1-2.4$ ) and

(O2) about our students' feedback on this course (section 2.5).

We will then

(O3) summarize our lessons learned (section 3.1) and

(O4) make recommendations for such international courses on HIS (section $3.2)$.

\section{The Frank - van Swieten Lectures}

\subsection{Objectives, Content, Structure, and Characteristics}

\section{Objectives}

The lecture in general aims to give students the competence to answer the following questions ([26], p. 2):

- Why is systematic information processing in healthcare institutions important?

- What are appropriate models for health information systems?

- How do health information systems look like and what architectures are appropriate?
- How can we assess the quality of health information systems?

- How can we strategically manage health information systems?

\section{Content}

The course content, based on the book presented in ([26]), is organized into the following topics, each forming one book chapter:

1. Introduction

2. Health Institution and Information Processing:

Significance of information processing in hospitals, progress in information and communication technology, importance of systematic information management.

3. Information System Basics:

Data, information and knowledge, information systems and their components, information management.

4. Health Information Systems:

Hospital information systems, transinstitutional HIS, electronic health records, and challenges for HIS.

5. Modeling Health Information Systems: On models and metamodels, a metamodel for modeling health information systems: $3 \mathrm{LGM}^{2}$, on reference models, a reference model for the domain layer of hospital information systems.

6. Architectures of Hospital Information Systems:

Domain layer - data to be processed and hospital functions, logical tool layer - application components and their integration, physical tool layer - data-processing systems and their integration.

7. Specific Aspects for Architectures of Transinstitutional Health Information Systems:

Domain layer, logical tool layer, physical tool layer.

8. Quality of Health Information Systems: Quality of structures, quality of processes, quality of outcome, balance as a challenge for information management, evaluation of health information systems quality.

9. Strategic Information Management in Hospitals:

Strategic, tactical and operational information management, organizational structures for information management, 


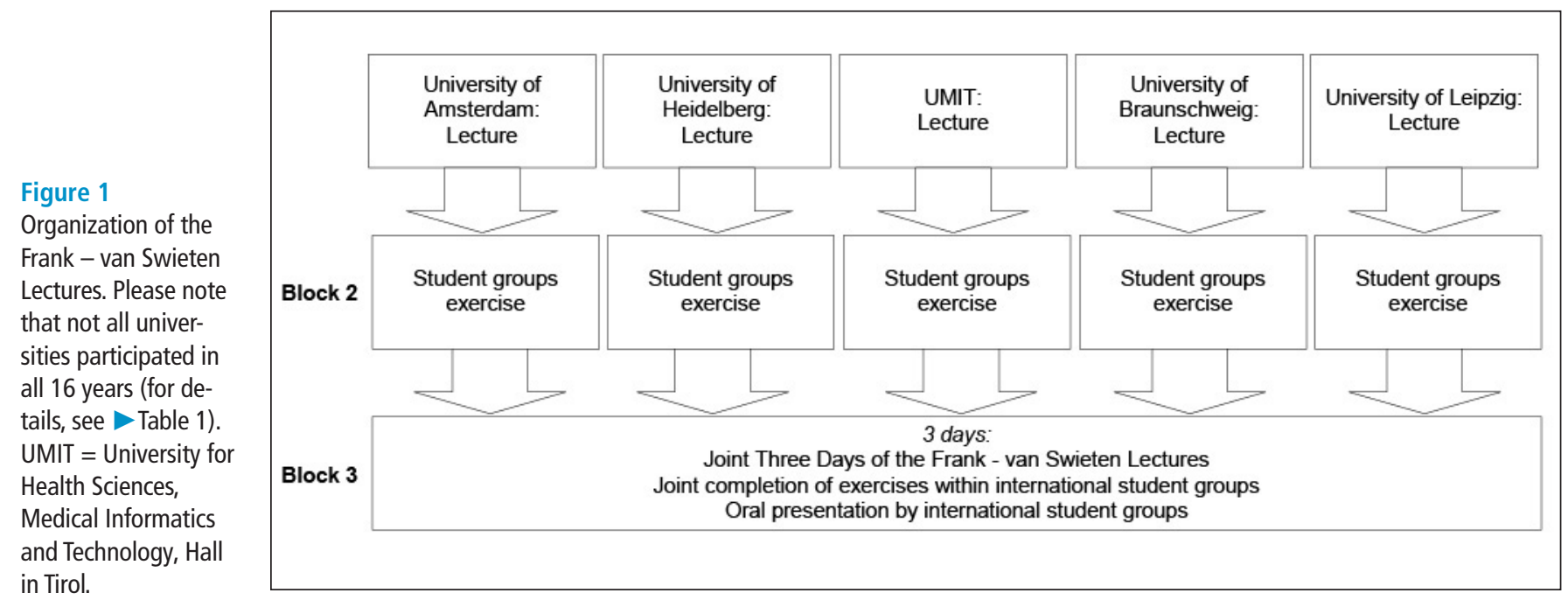

strategic planning, monitoring and directing of hospital information systems.

10.Strategic Information Management in Health Care Networks:

Description of health care networks, organizational structures of information management, types of health care networks.

11.Final Remarks

\section{Structure}

The course is yearly organized in three blocks ( Figure 1):

- Block 1: The contents of the book are taught separately by the teachers of the respective programs at the participating universities - either in Dutch or in German. Students are then introduced to their exercises. They are assigned to groups, each group looking at a given clinical/hospital area (e. g. cardiology, ophthalmology, emergency unit, patient administration). The choice of the areas is coordinated between all participating universities, so that international student groups covering the same clinical area can be formed.

- Block 2: Students start to work on their exercises. These exercises comprise the analysis and assessment of a part of their local hospital information system during short internships. Details of the exercises are presented further down. This block includes local site visits for each group in the respective clinical areas of the local medical centers, and a presentation of the overall architectures and infrastructures of the hospital information system.

- Block 3: Students and teachers meet for approximately three days at one of the participating universities, the so-called Joint Three Days of the Frank - van Swieten Lectures. There, they get additional lectures on hospital information systems, and they get an introduction to the local hospital information systems and their strategic information management of all participating sites. Students jointly finalize the international part of their exercises by comparing their respective results of Block 2 with matching groups at the other universities, and prepare their joint international presentations. Finally, each international student group jointly presents the results of their exercises.

Within the exercises, the students have to fulfil the following tasks:

- Describe the current state of the sub-information system in one typical area of your local medical center! Which enterprise functions are important? Which (computer-based and non-computerbased) application components are used? Which physical data processing systems are used?

- Develop a model of the information subsystem of the respective area and use the three-layer graph-based metamodel $3 \mathrm{LGM}^{2}$ as metamodel ([26], section 5.3, $[27,28,29])$. Describe one typical process in detail, using activity-diagrams and-use-case-diagrams of the Unified Modelling Language (UML) as modelling techniques.

- Assess the quality of information processing and the quality of the architecture and infrastructure of the area's information subsystem ([26], section 8). What are strengths and weaknesses? What are opportunities and threats? Analyse two of the main problems in detail and discuss possible solutions.

- Describe how the future sub-information system could look like, to solve the problems detected before.

- Describe the differences in the sub-information system (with focus on architectures, infrastructures and processes) between the different medical centers.

The structure of the lecture remained mostly unchanged during the 16 years. There were minor adaptations, though, based on the lessons learned and the student evaluation, including a more detailed guideline for the students on how to structure both the oral and the written presentations.

\section{Characteristics}

This course is, to our knowledge, unique. There are eight characteristics being essential for the Frank - van Swieten Lectures: $\chi_{1}$ Universities from different countries perform jointly a master/bachelor course.

$\chi_{2}$ The collaboration is multilateral and open for new partners. 
Table 1 Year, participating universities, and location of the Joint Three Days of the Frank - van Swieten Lectures.

\begin{tabular}{|c|c|c|}
\hline Year & Participating universities & $\begin{array}{l}\text { Location of the Joint Three } \\
\text { Days }\end{array}$ \\
\hline 2001 & $\begin{array}{l}\text { Amsterdam } \\
\text { Heidelberg/Heilbronn }\end{array}$ & Heidelberg \\
\hline 2002 & $\begin{array}{l}\text { Amsterdam } \\
\text { Hall i.T.* } \\
\text { Heidelberg/Heilbronn }\end{array}$ & Amsterdam \\
\hline 2003 & $\begin{array}{l}\text { Amsterdam } \\
\text { Hall i.T.* } \\
\text { Heidelberg/Heilbronn }\end{array}$ & Innsbruck \\
\hline 2004 & $\begin{array}{l}\text { Amsterdam } \\
\text { Hall i.T.* } \\
\text { Heidelberg/Heilbronn }\end{array}$ & Heidelberg \\
\hline 2005 & $\begin{array}{l}\text { Amsterdam } \\
\text { Braunschweig } \\
\text { Hall i.T. } \\
\text { Heidelberg/Heilbronn }\end{array}$ & Amsterdam \\
\hline 2006 & $\begin{array}{l}\text { Amsterdam } \\
\text { Braunschweig } \\
\text { Hall i.T. } \\
\text { Heidelberg/Heilbronn }\end{array}$ & Braunschweig \\
\hline 2007 & $\begin{array}{l}\text { Amsterdam } \\
\text { Braunschweig } \\
\text { Hall i.T. }\end{array}$ & Amsterdam \\
\hline 2008 & $\begin{array}{l}\text { Amsterdam } \\
\text { Braunschweig } \\
\text { Heidelberg/Heilbronn }\end{array}$ & Braunschweig \\
\hline 2009 & $\begin{array}{l}\text { Amsterdam } \\
\text { Braunschweig } \\
\text { Hall i.T. } \\
\text { Heidelberg/Heilbronn } \\
\text { Leipzig }\end{array}$ & Amsterdam \\
\hline
\end{tabular}

\begin{tabular}{|c|c|c|}
\hline Year & Participating universities & $\begin{array}{l}\text { Location of the Joint Three } \\
\text { Days }\end{array}$ \\
\hline 2010 & $\begin{array}{l}\text { Amsterdam } \\
\text { Braunschweig } \\
\text { Hall i.T. } \\
\text { Leipzig }\end{array}$ & Braunschweig \\
\hline 2011 & $\begin{array}{l}\text { Amsterdam } \\
\text { Braunschweig } \\
\text { Hall i.T. } \\
\text { Heidelberg/Heilbronn } \\
\text { Leipzig }\end{array}$ & Amsterdam \\
\hline 2012 & $\begin{array}{l}\text { Amsterdam } \\
\text { Braunschweig } \\
\text { Hall i.T. } \\
\text { Leipzig }\end{array}$ & Leipzig \\
\hline 2013 & $\begin{array}{l}\text { Amsterdam } \\
\text { Braunschweig } \\
\text { Hall i.T. } \\
\text { Heidelberg/Heilbronn } \\
\text { Leipzig }\end{array}$ & Amsterdam \\
\hline 2014 & $\begin{array}{l}\text { Amsterdam } \\
\text { Braunschweig } \\
\text { Heidelberg/Heilbronn } \\
\text { Leipzig }\end{array}$ & Braunschweig \\
\hline 2015 & $\begin{array}{l}\text { Amsterdam } \\
\text { Braunschweig } \\
\text { Leipzig }\end{array}$ & Leipzig \\
\hline 2016 & $\begin{array}{l}\text { Amsterdam } \\
\text { Braunschweig } \\
\text { Heidelberg/Heilbronn } \\
\text { Leipzig }\end{array}$ & Heidelberg \\
\hline
\end{tabular}

* before 2005: Innsbruck

$\chi_{3}$ The course has been held every year since 16 years.

$\chi_{4}$ At each university the course is integral part of a 'usual' master or bachelor program (or specialization within a program) and thus addresses not only a small subgroup of students (elite) but all students enrolled for the respective program.

$\chi_{5}$ Each year the course is held during the same period of time. It is based on the same curriculum and, since 2003, on the same textbook (now, since 2010, [26]).

$\chi_{6}$ The course combines theoretical parts (lectures) to teach knowledge about HIS and practical systems analysis parts (exercises) to give insight into real world information systems in health care and to train skills related to systems analysis.

$\chi_{7}$ Each year's course starts with local onsite lectures and exercises but culminates finally in an international gathering of all participating universities' students and lecturers at one place: the Joint Three Days of the Frank - van Swieten Lectures. Exercises are then finalized in project groups as an international teamwork.

$\chi_{8}$ Students train their English capabilities, learn about different countries' styles of HIS and experience different cultural backgrounds.

\subsection{Universities and Educational Programs Involved}

The participating students come (with some variations over the last 16 years, for details see $>$ Table 1) from the Medical Informatics bachelor program of the University of Amsterdam, from the Medical Informatics master program of the University of Heidelberg / University of Applied Sciences Heilbronn, from the Medical Informatics master program of the University for Health Sciences, Medical Informatics and Technology (UMIT) in Hall in Tirol, from the Computer Science (in Economics) master program of the University of Braunschweig, and from the Computer Science master program of the University 
of Leipzig. Overall, 517 students from these programmes participated.

\subsection{On the Name 'Frank - van Swieten Lectures'}

In June 2004, R.H. asked A.W.B. to give him the name of a famous physician who would be suitable as a patron for an International Course on Strategic Information Management in Health Information Systems with students from Amsterdam, Heidelberg/Heilbronn, and Hall in Tyrol (before 2005: Innsbruck), i.e. from the three educational programs, participating at that time in this course. A.W.B. suggested two historical figures who represented the trinational profile which was requested: Gerard van Swieten and Johann Peter Frank, two of the most outstanding medical representatives of Austria's Enlightened Despotism between 1750 and 1800 [30, 31, 32, 33, $34,35]$.

Gerard van Swieten (1700-1772) was born in Leiden/South Holland. He studied medicine and stayed in Leiden until 1745, when he became the personal physician of the Austrian Empress Maria Theresa (1717-1780) in Vienna. Van Swieten is well-known as a founder of the first Vienna Medical School and as a reformer of the Medical Faculty in Vienna. In this position he implemented a transformation of the Austrian health service and of medical education. Van Swieten played a pivotal role in the implementation of health reforms throughout the entire Habsburg Monarchy. He advocated more governmental involvement in health matters. The main sanitation reform, which had been put forward by van Swieten and was issued by Maria Theresa in 1770, reorganized administrative health structures in the entire monarchy. It comprised three parts: $1^{\text {st }}$ the structure and function of the sanitary network and administration, $2^{\text {nd }}$ the structure and the duties of medical practitioners, and $3^{\text {rd }}$ the prevention of epidemics. Due to his organizational work van Swieten can be characterized as a medical manager - long before this term was coined. His son Gottfried van Swieten (1733-1803) had his own career in government service and is remembered as a friend and creditor of Wolfgang Amadé Mozart (1756-1791).

Table 2 Year and analysed sub-information systems of the Frank - van Swieten Lectures. For 2008, no information is available.

\begin{tabular}{|c|c|}
\hline Year & Analysed sub-information systems \\
\hline 2002 & cardiology, laboratory, obstetrics/gynaecology, paediatrics, radiology \\
\hline 2003 & $\begin{array}{l}\text { administration, intensive care, internal medicine, laboratory, nuclear medicine, paedia- } \\
\text { trics, pharmacy, radiology }\end{array}$ \\
\hline 2004 & $\begin{array}{l}\text { administration, throat/nose/ear, intensive care, internal medicine, laboratory, nuclear } \\
\text { medicine, pathology, radiology }\end{array}$ \\
\hline 2005 & $\begin{array}{l}\text { administration, cardiology, ear, nose } \& \text { throat, intensive care unit, internal medicine, } \\
\text { laboratory, nuclear medicine, paediatrics, pharmacy, radiology }\end{array}$ \\
\hline 2006 & $\begin{array}{l}\text { accident surgery, , endocrinology, internal medicine, laboratory, nuclear medicine, pa- } \\
\text { thology, radiation therapy, radiology, revalidation, vascular medicine }\end{array}$ \\
\hline 2007 & $\begin{array}{l}\text { accident surgery, accounting, admission, internal medicine, nuclear medicine, paedia- } \\
\text { trics, pathology, radiation therapy }\end{array}$ \\
\hline 2009 & $\begin{array}{l}\text { cardiology, emergency care, intensive care, laboratory, nuclear medicine, pathology, } \\
\text { radiology, radiotherapy }\end{array}$ \\
\hline 2010 & $\begin{array}{l}\text { cardiology, emergency care, gynaecology, intensive care, laboratory, nuclear medicine, } \\
\text { radiology, radiotherapy }\end{array}$ \\
\hline 2011 & $\begin{array}{l}\text { archive, cardiology, emergency care, gynaecology, haematology, internal medicine, lab- } \\
\text { oratory, microbiology, neurology, nuclear medicine, oncology, psychiatry, radiology, } \\
\text { radiotherapy, surgery }\end{array}$ \\
\hline 2012 & $\begin{array}{l}\text { dental clinic, emergency care, endoscopy, internal medicine, laboratory, nuclear medi- } \\
\text { cine, radiology, radiotherapy, surgery }\end{array}$ \\
\hline 2013 & gynaecology, internal medicine, laboratory, nuclear medicine, radiology, radiotherapy \\
\hline 2014 & $\begin{array}{l}\text { anaesthesiology, dental medicine, ear, nose \& throat, gynaecology, microbiology \& im- } \\
\text { munology, nuclear medicine, pathology, oncology, orthopaedics, radiology, radiother- } \\
\text { apy }\end{array}$ \\
\hline 2015 & $\begin{array}{l}\text { anaesthesiology, ear, nose \& throat, gynaecology, transfusion medicine, heart center, } \\
\text { human genetics, immunology \& hygiene, intensive care unit, IT department, microbiol- } \\
\text { ogy, paediatrics, radiotherapy, radio oncology }\end{array}$ \\
\hline 2016 & $\begin{array}{l}\text { ambulatory center, cardiac surgery, clinical chemistry, gynaecology, IT departments, } \\
\text { nuclear medicine, radiology, radiotherapy, radio-oncology }\end{array}$ \\
\hline
\end{tabular}

Johann Peter Frank (1745-1821) was a famous physician and hygienist born near Pirmasens in Germany. He first studied theology, later medicine at the Universities of Strasbourg and Heidelberg, where he earned his medical doctorate in 1766 . In 1772 he became physician-in-ordinary to the Prince-Bishop of Speyer in Bruchsal. He was appointed professor of Physiology and Medical Police at the University of Goettingen in 1784, but only one year later he went to Italy and joined the Medical Faculty of the University of Pavia as the teacher of Clinical Medicine until 1795. Backed by the authority of the Austrian Emperor Joseph II (1741-1790), Frank reorganized the Medical School from the bottom. Clinical instruction was given by
Frank in the hospital wards. He established a surgical clinic and required that medical students had to attend surgical courses and students of surgery medical courses. In 1795, Emperor Francis II (1768-1835) employed Frank for the regulation of the sanitary service of the army and as Director General of the Principal Hospital of Vienna. In 1804 he went to Vilnius in Lithuania as professor of Clinical Medicine. From 1805 to 1808 Frank served as the personal physician to the Russian Czar Alexander I (1777-1825) in St. Petersburg. In 1808, he retired in disappointment and went back to Vienna. Johann Peter Frank was an important protagonist in social medicine; between 1779 and 1819 he published 6 volumes of a System of Complete Medical 
Table 3 Participating students, returned evaluation questionnaires and results to the question "C1. Overall, I think that I really benefited from the 3 days of international exchange (compared to only pure national lectures/exercises)." and "C2. Overall, I would recommend other students to participate next year in the international part of the HIS module." of the Frank - van Swieten Lectures. No evaluation was done in 2003, 2013 and 2014. Scale: (1) totally disagree, (2) partly disagree, (3) agree/disagree, (4) partly agree, (5) totally agree.

\begin{tabular}{|l|l|l|l|l|}
\hline Year & $\begin{array}{l}\text { Number of } \\
\text { students }\end{array}$ & $\begin{array}{l}\text { Number of returned } \\
\text { questionnaires }\end{array}$ & $\begin{array}{l}\text { C1 "I benefited" } \\
\text { (mean) }\end{array}$ & $\begin{array}{l}\text { C2 "I would recom- } \\
\text { mend it" (mean) }\end{array}$ \\
\hline 2002 & 30 & $28(93 \%)$ & 4.67 & 4.79 \\
\hline 2004 & 46 & $40(87 \%)$ & 4.54 & 4.63 \\
\hline 2005 & 77 & $66(86 \%)$ & 4.59 & 4.72 \\
\hline 2006 & 33 & $31(94 \%)$ & 4.24 & 4.26 \\
\hline 2007 & 44 & $37(84 \%)$ & 4.68 & 4.79 \\
\hline 2008 & 26 & $26(100 \%)$ & 3.96 & 4.12 \\
\hline 2009 & 62 & $48(77 \%)$ & 4.45 & 4.58 \\
\hline 2010 & 61 & $44(72 \%)$ & 4.21 & 4.32 \\
\hline 2011 & 64 & $50(78 \%)$ & 4.36 & 4.56 \\
\hline 2012 & 40 & $31(78 \%)$ & 3.65 & 3.76 \\
\hline 2015 & 34 & $27(79 \%)$ & 4.38 & 4.48 \\
\hline & Weighted mean: & 4.37 & 4.27 \\
\hline
\end{tabular}

Police, a comprehensive treatise on all aspects of hygiene and public health. Frank stressed the importance of keeping accurate statistical records for hospitals. His system of record compilation was used by obstetrician Ignaz Philipp Semmelweis (1818-1865) when in 1848 this one demonstrated the correlation between puerperal sepsis and unsanitary obstetrical practices.

\subsection{Analysed Sub-information Systems}

Each year, the exercises within the Frank van Swieten Lectures focussed on pre-defined sub-information systems. These subinformation systems were selected based on the availability of sufficient support in the respective departments, but also trying to have comparable sub-information systems in the participating universities, to allow forming of international student groups. - Table 2 shows the analysed subinformation system in the last 16 years.

\subsection{Student's Feedback}

To evaluate the Frank - van Swieten Lectures we conducted during its Joint Three Days a systematic evaluation with a structured questionnaire based on closed questions. The survey instrument was developed by the teachers of the Frank - van Swieten Lectures in 2001 and was used since then. As the instrument was not designed as psychometric questionnaire, no formal validation was conducted. Data analysis comprised the descriptive results for each question.

The evaluation took place from 2001 until 2016, except 2003, 2013 and 2014. A total of 553 students participated over the years in the Frank - van Swieten Lectures and 452 students returned the questionnaire. The questionnaire has a rating scale of one to five with the following meaning: (1) totally disagree, (2) partly disagree, (3) agree/disagree, (4) partly agree, (5) totally 2015) in a weighted average, taking into account the different number of students that participated each year.

Part $\mathrm{A}$ of the questionnaire was concerned with students opinions with regard agree. We combined the results (2001- to the overall structure, organization, content and outcome of the international course. The students indicted that they were sufficiently informed about the structure $(\mathrm{M}=3.80)$ and organization $(\mathrm{M}=$ 3.62). The students felt that they were sufficiently prepared by the initial lectures offered at their home university for the exercises and the international part of the course $(M=3,83)$.

Part B of the questionnaire was concerned with the personal assessment of the international course with respect to study effort of the international course, the beneficial effect of the international course. The students indicated that they found the exercises interesting and useful $(M=3,93)$, the students learned from the joint HIS lectures $(M=3,85)$, and benefited from exchanging ideas with students from other nationalities and the international discussions and presentations $(M=4,18$ and $\mathrm{M}=4,00$ respectively). Students stated that they made use of their time in the joint discussion groups to learn from each other and enjoyed the exchange of ideas on hospital information systems with other international students $(M=3,76$ and $M=4,21$ respectively). The students indicated that they learned about other hospital information systems besides their own hospitals and had a better insight into healthcare systems ( $M=4,00$ and $M=3,97$ respectively). Students indicated also that they improved their presentation skills and that they benefited with regard to professional knowledge and skills $(M=3,84$ and $M=4.08$ respectively). Finally the students enjoyed getting to know students from other nationalities $(\mathrm{M}=4,49)$.

Part $\mathrm{C}$ of the questionnaire was concerned with the overall assessment of the international course. Students indicated that they benefited from the international course and would recommend other students to participate $(M=4,37$ and $M=4,27$ respectively). - Table 3 shows details of this overall evaluation.

We also asked each student the questions (1) "What did you like best?", (2) "What did you like least? Changes next time?" and (3) "Most important thing learned?".

Here many responses of both (1) and (3) again positively highlighted the opportun- 
ity to meet and to collaborate with students from other countries and to communicate and to present in English. Also a better understanding of HIS architectures was often positively mentioned. Concerning (2) we received mainly comments on the intensive workload during the Joint Three Days and sometimes with respect to accommodation.

In the joint evaluations we could neither observe noticeable changes during the years nor in between the students of different universities. Although the questions of the joint evaluation were on the Frank van Swieten Lectures as a whole, responses focussed to some extent on the Joint Three Days, as the evaluation took place there.

\section{Lessons Learned and Recommendations}

\subsection{Lessons Learned}

As our students' feedback was clearly positive (cf. chapter 2.4), we were encouraged to continue with the course for now 16 years. The mostly highlighted aspects were the exchange, the communication and the joint activities with students from other universities, even of different nations. This shows us the relevance of such an international teaching effort.

As teachers in the field of HIS we observe an ongoing importance of strategic information management for medical informatics students and graduates. The Joint Three Days of the Frank - van Swieten Lectures show us each year that there are significant differences in the information systems of the hospitals of the different sites. Most interestingly these differences were bigger in the past. We now have realised that the information architectures of the local hospital information systems started to converge. For example, in all hospitals, a communication server is used as a central component, and 'patient management system', 'digital archiving system' and 'picture archiving and documentation system' are major hospital-wide application components. This used to be far more heterogeneous a decade ago. This shows the evolution of the field. In the next future more detailed implementation aspects and transinstitutional aspect may come into the focus of the analyses.

During all of the time when teaching the Frank - van Swieten Lectures we used $3 \mathrm{LGM}^{2}$ and UML for modelling hospital information systems. Since - to our knowledge - no better alternatives have shown up they proved its value and we will continue working with them.

During the course we continuously evaluated the students' feedback and our own experiences in order to regularly discuss potential improvements. Since it was always a challenge to identify similar clini$\mathrm{cal} /$ hospital areas in the different participating medical centers we had the idea to analyse and compare enterprise functions of the hospitals instead. This, however, did not prove successful, as it was much more difficult or even impossible to identify one contact person per enterprise function. So we finally continued with the clinical/hospital areas.

Anyway, for participating in the Frank van Swieten Lectures it is necessary to have good connections to a local teaching hospital where students are granted access to clinical departments and can interview hospital staff.

Very effective was the idea to integrate site visits into the Joint Three Days of the Frank - van Swieten Lectures. During the last years we have established that the hosting university offers our students visits to certain clinical/hospital areas, which are introduced by local staff.

Most interestingly, there is currently hardly any interaction among students from different universities outside the Joint Three Days. Although a collaboration platform had been offered over many years, the students did not use it. However, especially for a course with participants from different universities an e-learning platform like Moodle or Ilias could provide joint teaching materials, video-recorded lectures, a discussion forum for the student groups, knowledge tests and evaluation forms. This could strengthen the students' perception of the Frank - van Swieten Lectures as an international course beyond the three joint days.

The Joint Three Days are most helpful for the international exchange and are often filled with an intensive program. The time schedule is very tight and could easily be extended to four of five days to intensify the exchange and experiences. Nevertheless, we assume that this would exceed the reasonable effort given the universities' processes.

\subsection{Recommendations}

According to our experiences over the last 16 years we provide the following recommendations for establishing joint international courses, independent of a particular subject:

- Starting point should be a consensus about teaching material, which is ideally published with easy access for all participants, e. g. published as text book or provided by an e-learning course.

- The contents of this teaching material should be taught at each participating university before a joint meeting takes place (in our case the Joint Three Days).

- At the beginning of the joint meeting an initial lecture is helpful to start communication with a joint terminology.

- Offer team building activities at the first evening with mixed groups, so that students from different universities start to interact on a relaxed basis.

- It is crucial to identify similar areas for analyses at each of the participating hospitals and to have good contacts to people working there to organize the field work. If possible each group of students should have a counterpart from another university with the same scope in order to improve comparability and to stimulate discussions.

- During the field work close mentoring by an experienced teacher should be provided.

- Motivate students to use a collaboration platform and initiate students' interaction before the joint meeting.

- Establish a quality management of the lectures, e. g. by annual staff meetings to discuss experiences and limitation and to continuously improve the structure and processes of the international course.

- Make sure that the participation in the joint meeting is voluntary, but provide credit points for it. 
- Students in a master program might have more skills for systems analysis, for team work, and for English presentation than students in a bachelor program and might therefore have a greater benefit.

- An important prerequisite for international collaborations in teaching are national funds supporting academic teaching purposes. Every year, the participating groups are confronted with the problem of financing the students' trips to another city or country for the joint lectures. Unfortunately, from a German perspective we could not find appropriate dedicated funding programs for such recurring short-term excursions. E.g., the PROMOS funds, offered by the German Academic Exchange Service for German Students, are not available in certain universities, for study trips within Germany, and for foreign students studying at German universities.

\section{Discussion}

The recommendations made in section 3.2 actually intend to encourage readers to copy this program. Nevertheless we are aware of the fact that these recommendations are based on subjective experiences and by no means evidence based - although they are backed up by repeated and ongoing evaluations.

Of course, we are aware that having a partnership between three German, one Austrian and one Dutch University is not a very broad international collaboration. For students as well as teachers it would be even more exciting to have partners from countries with more different languages and cultural backgrounds. In this case the financial and organisation hurdles might turn out to become even bigger. So, in our opinion, a good compromise should be established.

The idea of supporting education, especially in biomedical and health informatics, by international collaboration is not unique. Also, the characteristics $\chi_{1}$ to $\chi_{8}$, mentioned in section 2.1 may be found in other programs and courses as well as can be seen by the following examples:
- A lot of institutions perform international collaborations in biomedical and health informatics (c.f. $\chi_{1}$ ). In order to support knowledge transfer from US universities to Peru a bilateral $\left(\chi_{2}\right)$ collaborative training program between the Universidad Peruana Cayetano Heredia and the University of Washington is working since 1999. Undergraduates are educated in Peru whereas key Peruvian faculty members undergo intensive trainings in the US [36].

- $\chi_{6}$, i.e. adding visits and systems analysis of real-life HIS to lectures on HIS, is used in other programs as well [37].

- Training computer science students for careers in global software projects $\left(\chi_{7}\right)$ dealing with different cultural backgrounds $\left(\chi_{8}\right)$ is a mayor driver for a Swedish-US collaboration. Rose-Hulman Institute of Technology (US) and Uppsala University (Sweden) define joint software projects in a real world environment (c.f. $\chi_{6}$ ) and elected students $\left(\chi_{4}\right)$ from US will come to Sweden to finalize the project with their Swedish fellow students [38].

- Since financial issues are considerable barriers for physical exchange of students in an international setting $\left(\chi_{7}\right)$ some educational collaboration projects use digital communication media for virtual collaboration as for example in a joint Swedish-US nursing education program [39].

- Adopting the long tradition of so called master classes in the performing arts a particular master class in health informatics had been established [40]. This educational program was also addressing international collaboration $\left(\chi_{1}\right)$ and physical gathering of students and lecturers at one site $\left(\chi_{7}\right)$. But - as usual with such master classes - there is no preceding joint course $\left(\chi_{3}-\chi_{6}\right)$ and no practical part $\left(\chi_{6}\right)$.

However, to our knowledge, the combination of the characteristics $\chi_{1}$ to $\chi_{8}$, described in section 2.1, in one program, makes the Frank - van Swieten Lectures unique.

Although associated with considerable additional efforts, we can clearly recommend establishing such international courses on HIS, such as the Frank - van Swieten Lectures.

\section{Acknowledgment}

Our universities and their sponsoring associations generously and continuously supported our Frank - van Swieten Lectures, despite of all challenges, such an unusual joint international course is causing. The hospitals at Amsterdam (AMC), Braunschweig (Braunschweig Medical Center), Heidelberg (Heidelberg University Hospital), Innsbruck (TILAK) and Leipzig (Leipzig University Hospital) always made it possible that our students could visit and analyze their clinical, administrative and IT departments. Last, but not least, our students continuously helped us during the last 16 years to improve this course by evaluating our lectures and by providing us with many constructive ideas and helpful comments ${ }^{\star}$. We cordially want to thank all of them.

\section{On the Authors' Roles at the Frank - van Swieten Lectures}

Within the Frank - van Swieten Lectures the authors had the following roles: E.A. has been lecturer at UMIT from 2005 to 2013, assistant lecturer at the University of Heidelberg in 2001 and at UMIT in 2002. P.K. has been lecturer at the University of Heidelberg since 2008. A.W. has been lecturer at the University of Leipzig since 2009. A.W.B. has been asked to search for appropriate names for the course and suggested the names Johann Peter Frank and Gerard van Swieten. O.J.B. has been assistant lecturer at the University of Braunschweig from 2005 to 2007. M.G. has been assistant lecturer at the University of Heidelberg since 2014. B.H. has been assistant lecturer at the University of Braunschweig in 2014. W.O.H. has been assistant lecturer at UMIT from 2009 to 2013. N.H. has been assistant lecturer at the University of Braunschweig from 2005 to 2008. G.H.B.

Some of them - B.H., W.O.H., N.H., G.H.B., C.M. B.O., J.S., N.S., A.S. and M.v.d.H. - became themselves lecturers after having been participating in this course as student! 
has been assistant lecturer at UMIT from 2003 to 2006. F.J. has been assistant lecturer at the University of Leipzig since 2009. M.W.J. has been among the initiators of this course in the context of IФE. U.K. has been lecturing parts of the course at the University of Heidelberg since 2010. C.M. $(\dagger)$ has been assistant lecturer at UMIT in 2007. B.O. has been assistant lecturer at the University of Braunschweig since 2016. J.P. has been assistant lecturer at the University of Heidelberg in 2008 and 2009. J.S. has been assistant lecturer at the University of Braunschweig since 2012. As $\mathrm{CIO}, \mathrm{C} . \mathrm{S}$. has been and is involved in presenting Braunschweig Medical Center's information system. As CIO, J.E.S. has been involved in presenting the information system of the University of Amsterdam's Academic Medical Center. As CIO, S.S. has been and is involved in presenting the information system of the University Hospital of Leipzig. K.S. has been assistant lecturer at the University of Heidelberg from 2008 to 2013. N.S. has been assistant lecturer at the University of Braunschweig in 2008 and 2009. A.S. has been assistant lecturer at the University of Leipzig in 2012. M.v.d.H. has been assistant lecturer at the University of Heidelberg from 2003 to 2006. R.H. was among the initiators of this course in the context of IФE and has been lecturer since 2001, from 2001 to 2005 at the University of Heidelberg, from 2001 to 2004 at UMIT, and since 2005 at the University of Braunschweig. W.J.t.B. has been course coordinator and lecturer at the University of Amsterdam since 2001.

\section{References}

1. World Health Assembly. Fifty-eighth Assembly (May 16-25, 2005), Resolution WHA58.28 [cited 2016 May 15]. Available from: http://www.who. int/healthacademy/media/WHA58-28-en.pdf.

2. Healy JC. The WHO eHealth Resolution - eHealth for all by 2015? Methods Inf Med. 2007; 46: 2-4.

3. Al-Shorbaji N. The World Health Assembly resolutions on eHealth: eHealth in support of universal health coverage. Methods Inf Med. 2013; 52: 463-466.

4. World Health Organization. Global Observatory for eHealth [cited 2016 May 14]. Available from: http://www.who.int/goe/en/.

5. Kay M, Santos J. Report on the World Health Organization Global Observatory for eHealth strategic planning workshop, April 2008. Methods Inf Med. 2008; 47: 381-387.
6. Reichertz PL. Hospital information systems - past, present, future. Key-note address during 'Medical Informatics Europe 84', 5th Congress of the European Federation for Medical Informatics, Brussels, September 10-13, 1984. Reprinted and first published in [7].

7. Kuhn KA, Giuse DA. From hospital information systems to health information systems. Problems, challenges, perspectives. Methods Inf Med. 2001; 40: $275-287$.

8. Haux R. Health information systems - past, present, future. Int J Med Inform. 2006; 75: 268-281.

9. Reichertz PL. Hospital information systems - past, present, future. Int J Med Inform. 2006; 75(3-4): 282-299.

10. Haux R. Medical informatics: past, present, future. Int J Med Inform. 2010; 79: 599-610.

11. Jahn F, Issler L, Winter A, Takabayashi K. Comparing a Japanese and a German hospital information system. Methods Inf Med. 2009; 48: 531-539.

12. Stroetmann KA, Artmann J, Stroetmann V. Developing national eHealth infrastructures - results and lessons from Europe. Proc AMIA Ann Symp. 2011: 1347-1354.

13. Winter A, Ammenwerth E, Bott OJ, Brigl B, Buchauer $A$, et al. Strategic information management plans: the basis for systematic information management in hospitals. Int J Med Inform. 2001; 64: 99-109.

14. International Medical Informatics Association, Working Group 1: Health and Medical Informatics Education. Recommendations of the International Medical Informatics Association (IMIA) on education in health and medical informatics. Methods Inf Med. 2000; 39: 267-277.

15. Mantas J, Ammenwerth E, Demiris G, Hasman A et al; IMIA Recommendations on Education Task Force. Recommendations of the International Medical Informatics Association (IMIA) on Education in Biomedical and Health Informatics. First Revision. Methods Inf Med. 2010; 49: 105-120.

16. Knaup P, Frey W, Haux R, Leven FJ. Medical informatics specialists: what are their job profiles? Results of a study on the first 1024 medical informatics graduates of the Universities of Heidelberg and Heilbronn. Methods Inf Med. 2003; 42: 578-587.

17. Mantas J, Diomidous M. Implementation and evaluation of the MSc course in health informatics in Greece. Methods Inf Med. 2007; 46(1): 90-92.

18. Nøhr C, Sørensen M. The Career Paths for Masters in Health Informatics in Denmark. Paper presented at IMIA Working Group on Health and Medical Informatics Education Meeting. Building Worldwide Capacity for the Health Informatics Workforce, Buenos Aires, Argentina; 2008 [cited 2016 June 19]. Available from: http://vbn.aau.dk/ files/16597939/The_Career_Paths.pdf.

19. Ammenwerth E, Hackl WO. Job Profiles of Biomedical Informatics Graduates. Results of a Graduate Survey. Methods Inf Med. 2015; 54: 372-375.

20. Macedo AA, Ruiz ES, Baranauskas JA. Survey of the Job Profiles of Biomedical Informatics Graduates. Methods Inf Med. 2016; 55: 473-477.

21. Jaspers MW, Gardner RM, Gatewood LC, Haux R, Leven FJ, et al. IPHIE: an International Partnership in Health Informatics Education. Stud Health Technol Inform. 2000; 77: 549-553.
22. Jaspers MW, Gardner RM, Gatewood LC, Haux R, Schmidt D, Wetter T. The International Partnership for Health Informatics Education: lessons learned from six years of experience. Methods Inf Med. 2005; 44: 25-31.

23. Haux R, Ammenwerth E, ter Burg WJ, Pilz J, Jaspers MW. An international course on strategic information management for medical informatics students: aim, content, structure, and experiences. Int J Med Inform. 2004; 73: 97-100.

24. Jaspers MW, Ammenwerth E, Ter Burg WJ, Kaiser F, Haux R. An international course on strategic information management for medical informatics students: international perspectives and evaluation. Int J Med Inform. 2004; 73: 807-815.

25. Haux R, Winter A, Ammenwerth E, Brigl B. Strategic information management in hospitals. An introduction to hospital information systems. New York: Springer; 2004.

26. Winter A, Haux R, Ammenwerth E, Brigl B, Hellrung N, Jahn F. Health information systems architectures and strategies. London: Springer; 2011.

27. Winter A, Haux R. A three-level graph-based model for the management of hospital information systems. Methods Inf Med. 1995; 34: 378-396.

28. Winter A, Brigl B, Funkat G, Häber A, Heller O, Wendt T. 3LGM2-modeling to support management of health information systems. Int J Med Inform. 2007; 76: 145-150.

29. Stäubert S, Schaaf M, Jahn F, Brandner R, Winter A. Modeling Interoperable Information Systems with 3LGM2 and IHE. Methods Inf Med. 2015; 54: 398-405.

30. Brechka FT. Gerard van Swieten and his world 1700-1772. The Hague: Martinus Nijhoff; 1970.

31. Fernández-Guerrero IM, Fernández-Guerrero C, Fernández-Cano A: A pioneering on medical education: The seminal text of J. P. Frank's De medicis peregrinationibus - Medical travels (1792). Educación Médica. 2016; 17: 29-34.

32. Frank JP. A system of complete medical police. Baltimore: Johns Hopkins University Press; 1976.

33. Gerster AG. The life and times of Gerhardt van Swieten. Johns Hopkins Hosp Bull. 1909; 20(219): 161-168.

34. Sechel TD. The emergence of the medical profession in Transylvania (1770-1848). In: Karady V, Török BZ, editors. Cultural dimensions of elite formation in Transylvania (1770-1950). Cluj-Napoca: EDRC Foundation; 2008. p. 95-114.

35. Sigerist $H$. The people's misery: mother of diseases. An address, delivered in 1790 by Johann Peter Frank in Pavia. Translated from the Latin, with an introduction. Bull Hist Med. 1941; 9: 81-100.

36. Curioso WH, Fuller S, Garcia PJ, Holmes KK, Kimball AM. Ten years of international collaboration in biomedical informatics and beyond: the AMAUTA program in Peru. J Am Med Inform Assoc. 2010; 17: 477-480.

37. Haux R, Ammenwerth E, Häber A, Hübner-Bloder G, Knaup-Gregori P, Lechleitner G, Leiner F, Weber R, Winter A, Wolff AC. Medical informatics education needs information system practicums in health care settings - experiences and lessons learned from 32 practicums at four universities in two countries. Methods Inf Med. 2006; 45: 294-299. 
38. Laxer C, Daniels M, Cajander A, Wollowski M. Evolution of an International Collaborative Student Project. ACE '09 Proceedings of the Eleventh Australasian Conference on Computing Education. 2009; 95: 111-118.

39. Wihlborg M, Friberg E. Framework for a virtual nursing faculty and student learning collaboration between universities in Sweden and the United States: A theoretical paper. Nurse Educ Today. 2016; 41: 50-53.

40. Gatewood L, Limburg M, Gardner R, Haux R, Jaspers M, Schmidt D, et al. International Master Classes in health informatics. Int J Med Inform. 2004; 73: 111-116.

\section{Addresses of First and Senior Authors}

Prof. Dr. Elske Ammenwerth

Institute of Medical Informatics

UMIT - University for Health Sciences, Medical Informatics and Technology

Eduard-Wallnöfer-Zentrum 1

6060 Hall in Tirol

Austria

E-mail: elske.ammenwerth@umit.at
Prof. Dr. Petra Knaup

Institute of Medical Biometry and

Informatics

University of Heidelberg

Im Neuenheimer Feld 130.3

69120 Heidelberg

Germany

E-mail:

petra.knaup@med.uni-heidelberg.de

Prof. Dr. Alfred Winter

Institute for Medical Informatics, Statistics and Epidemiology

University of Leipzig

Härtelstr. 16-18

04107 Leipzig

Germany

E-mail: alfred.winter@imise.uni-leipzig.de
Prof. Dr. Reinhold Haux

Peter L. Reichertz Institute for Medical

Informatics

University of Braunschweig - Institute of Technology and Hannover Medical School

Mühlenpfordtstr. 23

38106 Braunschweig

Germany

E-mail: reinhold.haux@plri.de

Willem Jan ter Burg, MSc

Department of Medical Informatics

Academic Medical Center

University of Amsterdam

P.O.Box 222700

1100 DE Amsterdam

The Netherlands

E-mail: w.j.terburg@amc.uva.nl 